\title{
METHODOLOGICAL ASPECTS OF AERONAUTICAL SYSTEM UPGRADE
}

\author{
Alexei Samkov $^{1}$, Galyna Suslova ${ }^{1}$, Vladimir Litvinenko ${ }^{2}$, Yurii Zakharchenko ${ }^{1}$ \\ National Aviation University ${ }^{\prime}, 1$ Kosmonavta Komarova Ave, Kiev, Ukraine \\ Kherson National Technical University ${ }^{2}, 24$ Beryslavska rd St., Kherson, Ukraine \\ E-mail:eduicao@nau.edu.ua
}

Received 04 October 2010; accepted 10 October 2010
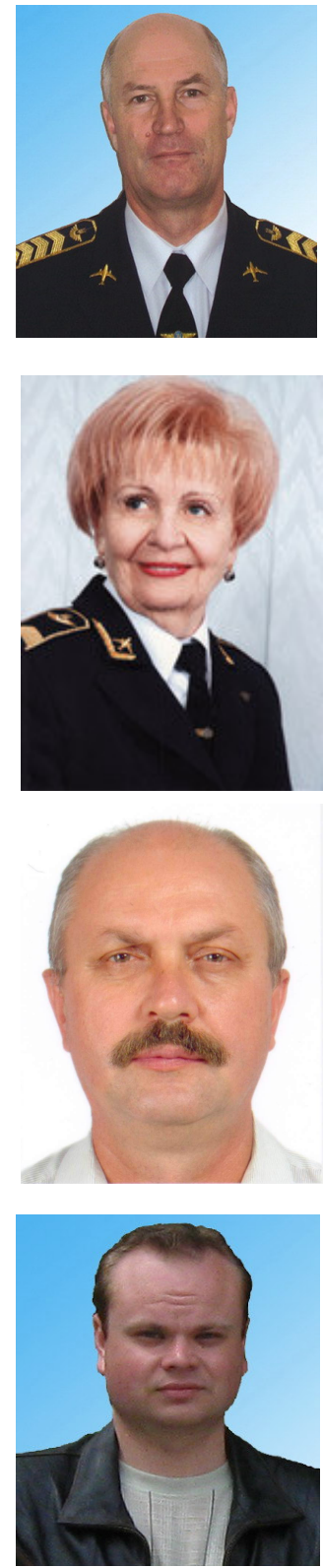

Alexei SAMKOV, Prof Dr Sci Eng

Education: Kiev Higher Educational Institution of Aviation Military Engineering.

Affiliations and functions: head of automation and energy management at National Aviation University.

Research interests: technical cybernetics and system methods of aircraft upgrading.

Galyna SUSLOVA, Prof

Education: Gorkovskiy State University.

Affiliations and functions: an Honoured Worker in education of Ukraine, an honorary professor of Korea Aerospace University (South Korea) and Vilnius Gediminas Technical University (Lithuania), Head of ICAO Training Institute, ICAO expert.

Research interests: safety management system, training of aviation specialists.

Vladimir LITVINENKO, Assoc Prof PhD

Education: Kherson Polytechnic Institute.

Affiliations and functions: associate professor at Kherson National Technical University.

Research interests: technical cybernetics and programming.

\section{Yurii ZAKHARCHENKO}

Education: Kherson National Technical University.

Affiliations and functions: post-graduate student at National Aviation University

Research interests: technical cybernetics and the system methods of aircraft upgrading, programming. 
Abstract. This article is devoted to the methodological aspects of upgrading aircraft, including the complex of mathematical methods, algorithms and criteria which allow the objective of the assigned research problem to be met.

Keywords: aeronautical system, immune algorithm, clonal immune algorithm, Bayesian networks, project management, efficiency, quality and flight safety criteria, decision making and optimisation methods.

\section{Introduction}

The modern aviation market sets strict requirements for the continuous upgrading of aircraft. First of all, this is the result of growing requirements for flight safety, efficiency, and the economic feasibility of aircraft operation. Realisation of these requirements is based on the implementation of the results of next-generation scientific research either in the process of the development of new types of aircraft or during the upgrade of existing types. The urgency of upgrading aircraft in the modern environment is caused by the abrupt increase in aircraft cost, global economic crisis, and the continuous process of the ageing of aircraft fleets. Upgrading aircraft means upgrading obsolescent and aged types of aircraft by means of the development of designs, components, materials and manufacturing technologies aiming to enhance performance and increase operating efficiency.

Upgrading aircraft allows not purchasing new aircraft but raising an ageing aircraft fleet to a level meeting modern requirements while costs are tenfold less. Therefore, upgrading aircraft has become a priority trend for the majority of countries such as the USA, Russia, Great Britain, France, etc. Military aircraft bombers (the B-52, the Tupolev 95) and fighters (the F-16, the MiG-21, the MiG-23, etc.) have gained world acknowledgement and after numerous upgrade procedures continue to operate, meeting modern requirements for aircraft. Upgrading aircraft is widely used in civil aviation as well. Numerous passenger and cargo aircraft continuously undergo upgrading to meet growing ICAO requirements.

\section{Direction of upgrade of airplanes An-125 in version An124-100M-150}

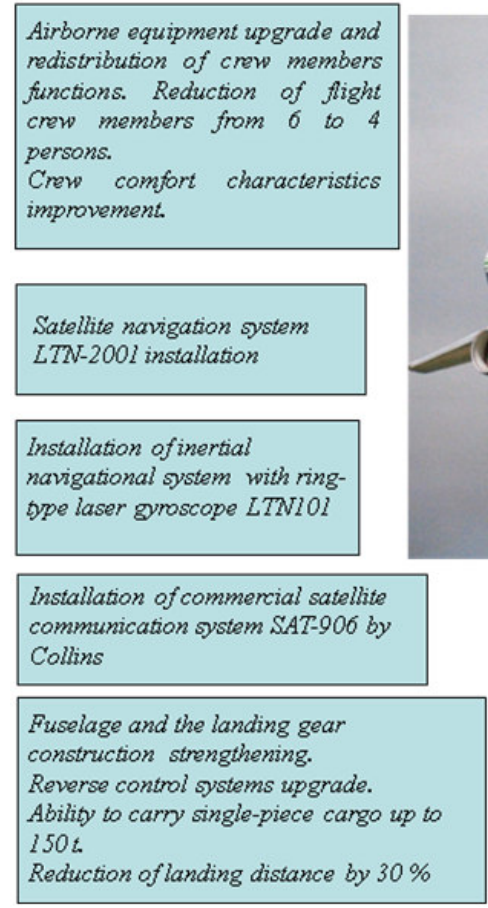

Fig 1. Basic upgrade aspects of the Antonov 124 cargo aircraft in the Antonov 124-100M-150 version
Thus, due to upgrade, one of the world's largest cargo aircraft - the Antonov 124 - has considerably extended its operational performance, met ICAO noise level acceptability and navigation accuracy requirements, etc. Take-off mass and payload of the Antonov 124-100M150 version have been increased to 402 tonnes and 150 tonnes. Its performance has been enhanced and flight safety has become higher respectively (Fig 1). The upgraded Antonov 124-100M-150 is now equipped with modern airborne systems, among which: The Traffic Col- lision Avoidance System TCAS-2000, the area navigation system BRNAV, Terrain Awareness and Warning System TAWS (TTA-12), and others.

The effective realisation of upgrading aircraft is closely connected with the assessment of its necessity, determination of the optimal modernisation version, and implementation of modernisation plans. 


\section{Basic research}

Realisation of these tasks requires development of the methodological aspects of upgrading aircraft. These should become the basis for the development of integrated guiding materials and manuals. In turn, these materials should determine the expediency of the upgrade decision as well as the efficiency growth levels and implementation costs. Such provisions should include a complex of methods, procedures, algorithms and criteria. Research resulting in scientific and practical findings has been performed (Клишин 1999; Самков и др. 2004; Самков 2008; Самков $u$ др. 2006; Самков и дp. 2009; Захарченко $u \partial p$. 2009). Thus, the reasonability of the aircraft and aeronautical system upgrade decision has been defined; on the basis of upgrade alternative synthesis, optimal aircraft upgrade versions have been defined and optimal implemen-tation plans have been developed, etc. (Самков и др. 2004; Самков 2008; Самков и др. 2006; Самков $и$ дp. 2009; Захарченко $u$ дp. 2009).
In addition to that, deficiencies in upgrading aircraft in the modern environment are directly connected with lack of resources (first of all, financial), uncertainty of their availability, support compatibility problems of domestic and foreign technology and components, aircraft patterns fixed resource indices projection need, absence of designers and aircraft manufacturers, etc.

Resource shortage issues during the implementation of an aircraft fleet upgrade program and uncertainty of their availability are, indisputably, topical. Shortage can result in million dollar wastages. A congruent complex of scientific tasks must be solved and engineering provision for upgrading aircraft must therefore be generated.

The resolution of the tasks necessary to upgrade an aircraft fleet has two counter trends: on the one hand it is necessary to develop aircraft and aeronautical system upgrade alternatives that would meet global standards for an extended period of time; on the other hand, the resources of the customer and entity performing the upgrade are limited and require continuous correction of alternatives for cost reduction.

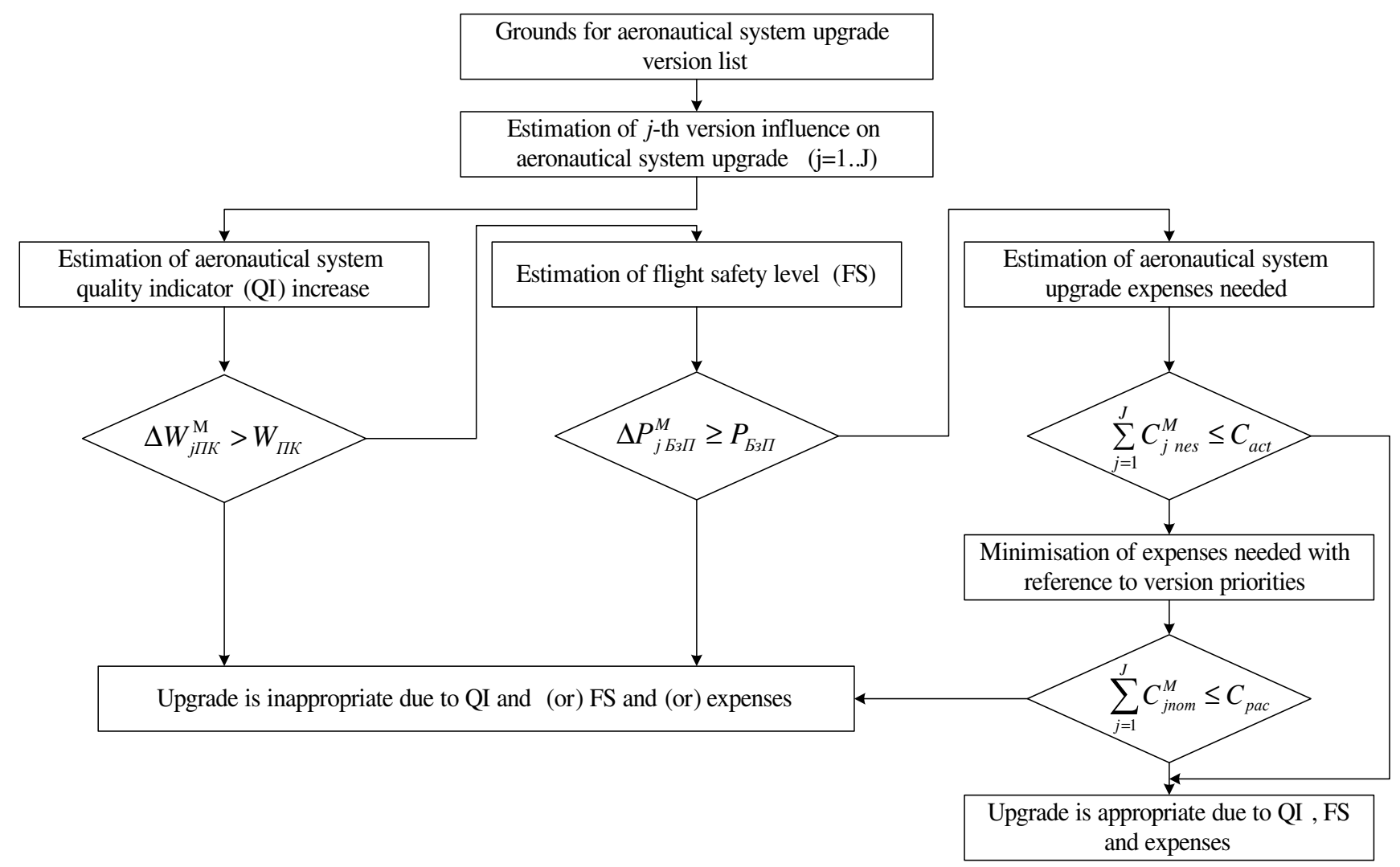

Fig 2. Algorithm of formation of aeronautical system upgrade version list

These contradictions cause a scientific problem in developing the methodological aspects of upgrading aircraft in consideration of limited resources. In order to solve the abovementioned research problem, it is suggested that upgrading should be considered with the application of a system approach at the level of the aircraft fleet, researching the aeronautical system comprising aircraft, ground handling facilities, airfield technical support, and communication and control facilities.
Formalisation of the mathematical research problem was performed for determining the following characteristics of the aeronautical system: problems, which will be solved after the upgrade of the aeronautical system and upgrade project funds and the terms of their receipt. Performing synthesis of aeronautical system upgrade versions together with allocation of resources in the process of realising upgrade projects was also suggested. Along with this, during the decision making process priority is 
given to the attainability of the projects over the synthesis problem and can correct or restrain the upgrade version decision. For instance, in case of shortage of financial resources on project implementation, reduction of the number of aeronautical systems for upgrade is possible, as well as giving preference to the upgrade version with reduced (simplified) complexity of equipment, etc.

Most known scientific approaches to solving the upgrade version synthesis problem are based on economical efficiency criteria. As opposed to them, the triad of criteria that considers the most crucial ICAO requirement for aviation safety (SMS) is suggested (Руководство... 2009). This triad includes the well-known cost (expense) criterion (C), suggested aeronautical system potential efficiency criterion (PEC), and flight safety criterion (FS), which in its turn has priority over the cost (Fig 2). The main methodological aspects of the grounds for the choice of upgrade versions guided by PEC, FS and C criteria are based upon methodological and optimisation decomposition, including:

- single criterion optimisation, with the help of which early stage upgrade decisions are made;

- multi-criteria optimisation, on the basis of which effective decision-making domains and optimum upgrade versions are set;

- decision making for comparative assessment of upgrade versions based on the complex of indicators, which besides quantitative indicators includes qualitative indicators.

To develop aeronautical system upgrade versions, an approach, which considers structural-functional method based on graph theory, is applied. It allows matching equipment, which is being upgraded with established objectives.

In order to carry out the comparative analysis of aeronautical system upgrade versions, methodological approaches are developed applying the suggested triad of criteria. On the basis of qualimetry theory, a PEC increase method for an aeronautical system was developed. It becomes possible due to its technical development. This improvement takes into consideration the relative increase in aeronautical system characteristics that are compared and its contribution to PEC. The suggested method considers various objectives of aeronautical system performance and carries out selection of upgrade alternatives rationally.

Main stages of comparative analysis and selection of aeronautical system upgrade versions are aeronautical system essential performance list, estimation of significance for aeronautical system, analysis of characteristics, determination of objective function assessment, and choice.

The method for evaluating significance was developed during the creation of the aeronautical system performance list and estimation of its importance. This method is based on regressive analysis, expert analysis, and theory of experiment planning.

The probability of successful flight is suggested as an aircraft flight safety index. Calculation of this parame- ter is carried out by means of logic-probability method. This method stipulates the development of an aircraft condition graph and probabilistic estimation of its final stages. The method for the determination of actual aircraft flight safety level depends on the upgrade version of the aeronautical system.

The problem of resource allocation can be solved under various conditions of material and financial provision during the upgrade of the aircraft fleet. In this case the cases of sufficient and insufficient supply of resources as well as the receiving of these resources under equivocal conditions are possible. In such conditions, it is important for the planning stage to know the results of the solution of the problems, i.e. to find the rational alternatives of upgrading the aeronautical system, the required time limits, the amount of financing, manufacturing resources, and the main aspects of the aeronautical system upgrading project.

With the application of the suggested criteria, methods and techniques for choosing the variants of upgrading an aeronautical system, the following synthetic method for conditions of sufficient resources is developed. It is given as an algorithm in figure 3 .

For conditions of insufficient resources for aircraft fleet upgrading, the algorithm and synthetic approach to variants of aeronautical system upgrading is developed under staged resources supply, applying the cost per unit indicator increase PEC (Самков $u$ дp. 2004; Самков 2008).

Implementation of the synthetic task allows coming to the problem of modern project management and formation of rational plans for its realisation. The success of the project and the expenses upon realisation depend on the results of problem management (Самков $u \partial p$. 2004). Problem management has its difficulties due to the factor of uncertainty and lack of an effective mathematical method. This requires the development of appropriate methodology that will be able to maintain decision, making under conditions of uncertain supply of different resources during upgrading of aircraft.

The result of this problem management is the rational distribution of technical and human resources during the planning and project management of aircraft upgrading. A proved plan including uncertainty of receipt of resources will be able to provide the needs of the project.

During research the method and model of problem management of modern project management was developed by applying modern methodology - immune algorithm (Самков $u$ дp. 2008). The application of the following method allows mistakes to be reduced while planning aircraft upgrading and increases the validity of practical recommendations under the conditions of uncertainty in supply of resources.

The complex of aeronautical system characteristics, manufacturing capacity of upgrade, and its requirements are chosen as the initial data of the research problem. Factors of uncertainty stand for the total amount and time frames of receipt of finances. 


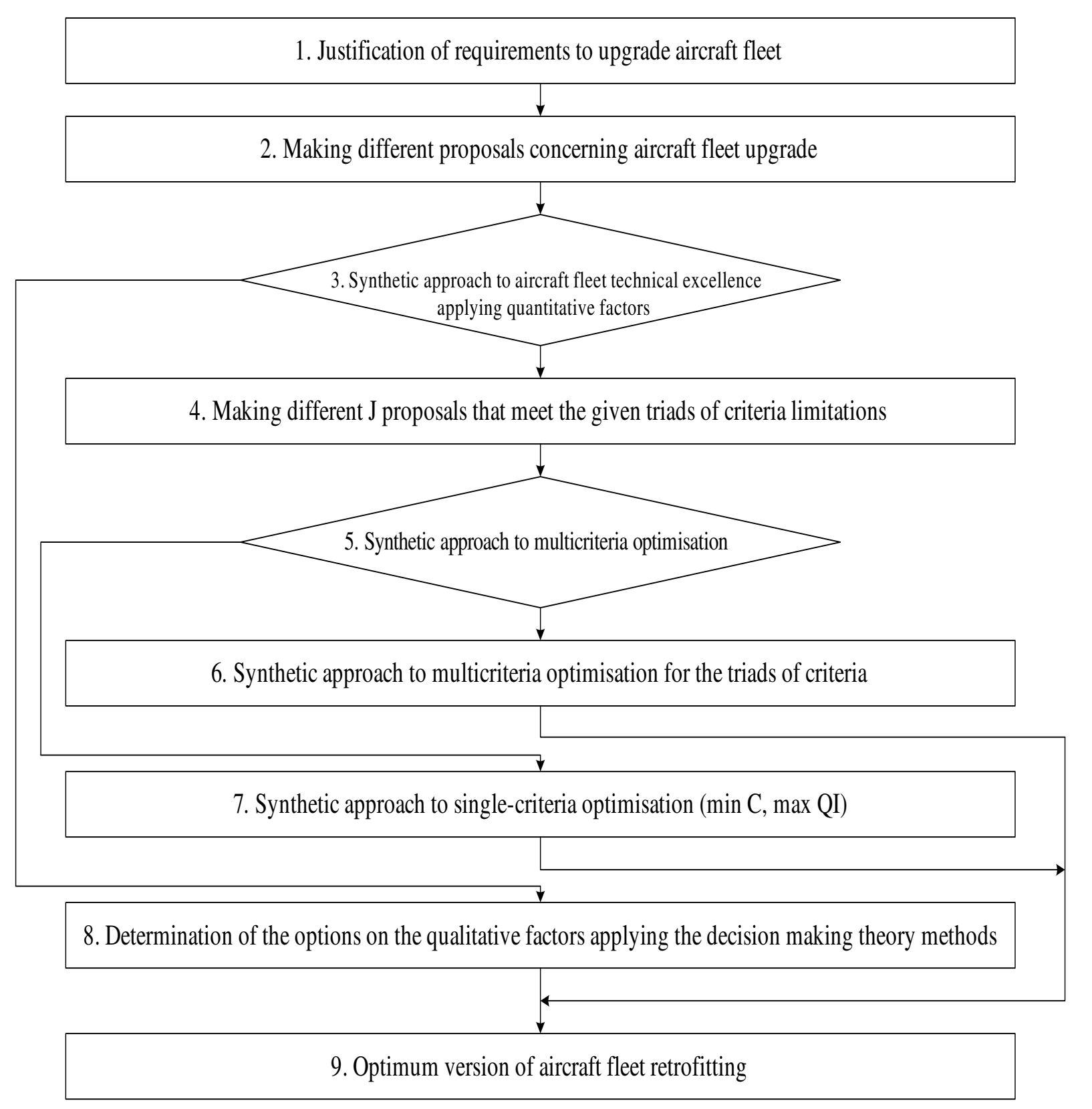

Fig 3. Stages of the synthetic methods of aircraft fleet modernisation versions with sufficient resources

Stochastic problem is researched including the existence of uncertainty It consists of finding the rational alternative of upgrade for each type of aeronautical system. After upgrade it allows providing the maximum objective of mathematical expectance and increase in aeronautical system potential effectiveness, within an uncertain amount, dates of financing, a deadline, and upgrade budget limitations.

The aeronautical system upgrade plan in general is determined by various characteristics (1) (Самков 2008; Самков $u$ дp. 2008):

$$
\operatorname{Pl}(\mathrm{x}, \mathrm{u}, \xi)
$$

where $\{x\}$ - definite characteristics consisting of finite elementary sets and characterized by vector of parameters:

- $\{A\} \neq \varnothing-$ set of $\mu^{\text {th }}$ types of aeronautical system that are subjected to upgrade;
- $\{B\} \neq \varnothing-$ set of characteristics for $j_{x}$ alternatives of aeronautical system upgrade;

- $\{D\} \neq \varnothing-$ set of enterprise manufacture capacity characteristics where the upgrade is planned to be carried out; - $\{E\} \neq \varnothing-$ set of upgrade plan characteristics;

$\{u\}-$ aw $u(t)$ of distribution of financial resources;

$\{\xi\}$ - upgrade uncertainty characteristics.

The objective is to find a plan $P l(x, u, \xi)$ for rational resource distribution $\mathrm{u}=\varnothing(\mathrm{u} 1, \mathrm{u} 2, \ldots, \mathrm{uk}), \mathrm{u}_{\mathrm{opt}} \in \mathrm{u}$ for $\mu$ types of aeronautical systems, which, taking into consideration all jx variants of upgrade, ensures the maximum increase in the aircraft fleets potential effectiveness (capabilities) ratio within the limits (2):

$$
\left\{\begin{array}{l}
\sum_{\mu=1}^{M} s_{\mu} \leq S_{e s t} \\
T_{t o t} \leq T_{e s t}
\end{array}\right.
$$


where $s_{\mu}$ - the amount of finances allocated for $\mu$-type of aeronautical system upgrade; $S_{\text {est }}$ - finances allocated for the upgrade program; $T_{\text {tot }}, T_{\text {est }}-$ time frames given for upgrade of fleet (total and estimated time of upgrade accordingly).

The process of developing a plan for upgrading an aircraft fleet can be delivered in the scheme (where $N_{\mu}$ types of aeronautical systems, $V_{\mu o}$ - alternatives of upgrade in accordance with types of aeronautical systems) that describes income of finances (amount and time frames), the procedure of distribution of finances, estimation of plan fulfilment, plan deviation, etc. (Fig 4). At the final stage, the optimal (rational) plan for upgrading an aircraft fleet is formed.

Since the theme being researched is an $\mathrm{Np}$ complicated discrete optimisation issue, the heuristic approach on the basis of clonal immune algorithm is suggested (Самков $u$ др. 2006; (Самков $u$ др. 2009; ICAO... 2001).

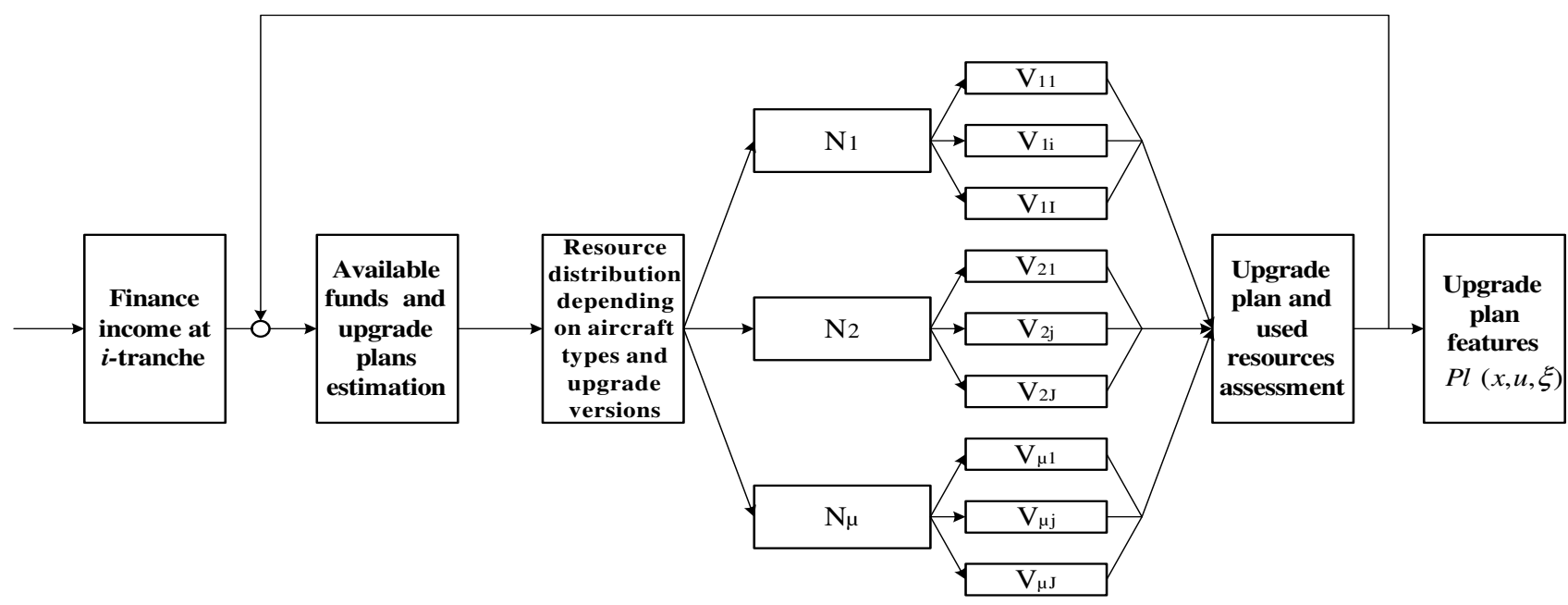

Fig 4. Layout of plan formation management for upgrading aircraft fleet

\section{Experimental research}

For clonal immune algorithm elaboration, it is necessary to consider the concept of antibodies (individuals), affinity function, and reproduction process, including selective clause, cloning and mutation of antibodies as the solution of the problem (Leonardo et al. 2002; Ong et al. 2005).

One of the most convenient concepts of solving this problem is 3D matrix approach where axes are: aeronautical systems, distributed in accordance with productive capacity for upgrade, variants of all types of aeronautical systems upgrades, and upgrade operations.

To implement the clonal selection algorithm and develop the upgrade plan, operations and resource limitations are introduced as antibodies. Such formalisation represents a work schedule sequence with notification regarding fulfilment or non-fulfilment of certain tasks.

On the basis of analysis of dispatch list by means of incomplete enumeration method, the resulting timetable of the project is developed. The crucial condition for such formalisation is the requirement of the uniqueness of antibody genes, which are stipulated for every operation or resource usage enrolment only once.

The antigen is described as an integral line, where cells are introduced as a checklist of tasks for planning, and each element of the line corresponds to an identically defined operation for planning.

The main stages of the clonal selection algorithm are selected as following:
1. Creation of initial pool of antibodies (m) (alternative solutions);

2. Calculation of similarity of antibodies;

3. Selection of the fittest individuals from the original antibodies $(\mathrm{n}<\mathrm{m})$ by the calculation of the similarity ratio;

4. Disposition of every selected $n$ individual in $n$ separate pools, here and after elite pools.

5. Hypermutation of every clone in all pools;

6. Determination of the fittest antibodies among those mutated for the next formation of elite pools;

7. Introduction of $k$ random antibodies in each pool in order to avoid falling into local optimum search;

8. Determination of condition for scheduling. If conditions are not suitable, then proceed to stage 4 (Leonardo et al. 2002; Ong et al. 2005).

However, the application of abovementioned algorithm does not take into consideration risk factors, original data inaccuracy, etc., so it allows only to a certain extent solving problems of uncertainty during upgrade. To solve this problem, the Bayesian networks (BN) method was suggested (Самков $u$ др. 2009). Developing a hybrid approach with integration of Bayesian networks and artificial immune systems was also suggested. In this approach artificial immune systems function as effective computing facilities for enumeration.

The main advantages of the BN method in comparison with the usual mathematic models are: intuitively obvious and grounded representation of correlation ar- 
guments; possibility of variable, not only as argument but also as required object within one structure; possibility of information dissemination in both directions of BTN (Самков $и$ др. 2009; Jensen 1996; Jensen 2001). Probabilistic distribution for all variables of the network during management of aircraft upgrading projects can be described by Bayes' theorem and two rules of probability calculation.

The example of BN for a fragment of the schedule for AE upgrade projects is given in figure 5.

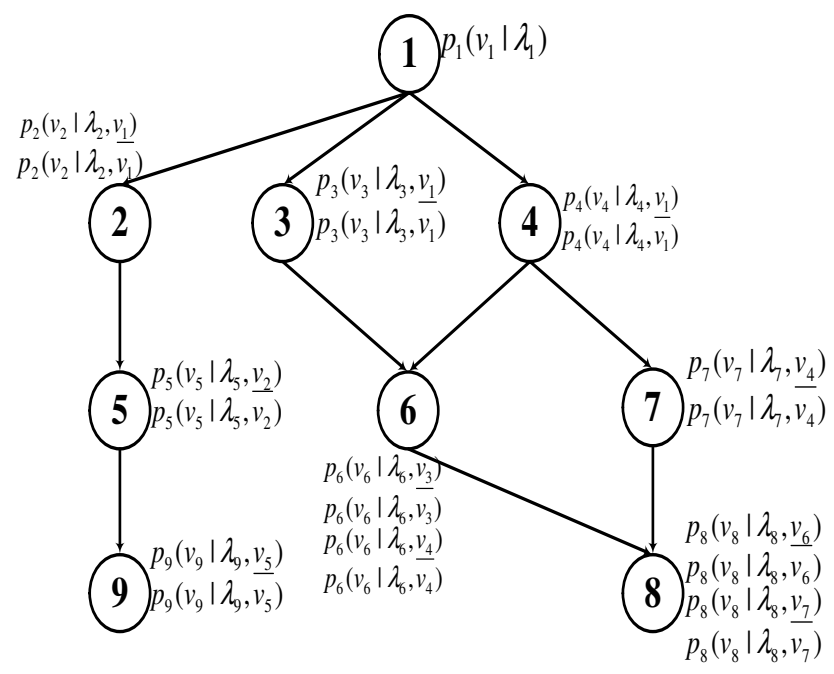

Fig 5. BN of probability calculation for realization of aircraft upgrading plan

Computation of marginal probability peaks for the final stages of the upgrade is carried out taking into consideration direct information dissemination in $\mathrm{BN}$ :

$$
p_{s}\left(v \mid G_{s}, \lambda\right)
$$

where $p_{s}$ is conditional probability of the $v$ event occurrence, notably current stage completion with results of generic stages $G_{s}$ regarding given one and known information about the current stage (Jensen 1996; Jensen 2001).

For example, for variant $p_{5}$ (Fig 5) such probability is computed by means of the following expression: $p\left(v_{5}\right)=\sum_{v_{2}}\left(p_{5}\left(v_{5} \mid \lambda_{2}, v_{2}\right) \cdot \sum_{v_{1}}\left(p_{2}\left(v_{2} \mid \lambda_{2}, v_{1}\right) \cdot p_{1}\left(v_{1} \mid \lambda_{1}\right)\right)\right)(4)$

The next step is the aircraft (1) upgrade plan check for working within limitations (2) of finance for the upgrade project and time for the aircraft upgrade $T_{t o t} \leq T_{e s t}$. The operating rate of AS upgrade is scheduled simultaneously with optimisation.

The schedule obtained should meet the following requirements:

- peak operating rate of manufacture capacity and upgrade of aeronautical systems should not exceed existing reserve;

- financial cost for upgrade of aeronautical systems during the entire process should not exceed the sum given for this certain period of time.

The procedure for financing the upgrade of aeronautical systems can be described as the aeronautical systems temporal finance distribution $C(t)$ function, and total operating rate of $j$ type as $\mathrm{R}_{\mathrm{j}}$. Basing on the gained optimisation of plans such a range positional relationship $t_{i}$ is determined; this relationship should provide correspondence with the abovementioned requirements, taking into consideration the decrease in total time for program implementation $T_{\text {tot }}$ within $T_{\text {tot }} \leq T_{\text {est }}$ limitations.

The BN-based method has allowed the upgrade model of aeronautical systems to be elaborated, taking into consideration uncertainty when the information concerning upgrade resources is given during the initial stage. The overall necessity analysis of these resources is carried out. In the next stage, by means of the immune algorithm, the problem of optimal resource distribution for the upgrade of aeronautical systems is solved, a set of schedules is created, and the best one is chosen.

To solve upgrade project management tasks, the conceptual approach to upgrading the aircraft fleet and structural-functional model of upgrading aircraft by applying artificial immune systems and BN were developed (Fig 6). The application of the suggested model allows scheduling the upgrade of aeronautical systems, taking into account all aforementioned conditions and limitations.

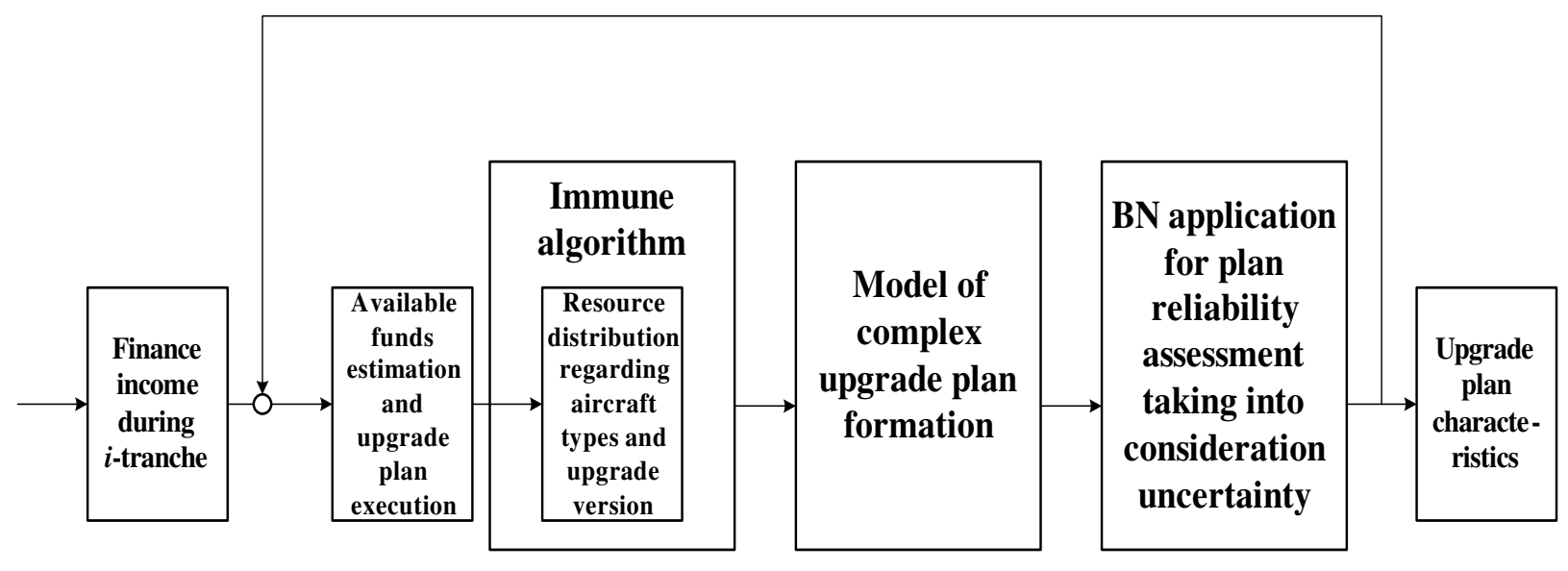

Fig 6. Structural-functional model of development of plan for upgrading aircraft fleet 
The suggested model of aircraft upgrades plans and combined application of artificial immune system algorithms with $\mathrm{BN}$ methods allows better results to be received in uncertain conditions. The application of this methodological approach increases the reliability of results for upgrade feasibility due to resource input uncertainty and decreases untenable capital input.

\section{Conclusions}

As a result of this research, the scientific problem of creating methodological aspects for upgrading an aircraft fleet with limited resources and uncertain input was solved.

\section{References}

ICAO Safety management manual. 2009. 2 nd ed. (9859AN/474).

Jensen, F. V. 2001. Bayesian Networks and Decision Graphs. Springer.

Jensen, F. V. 1996. Bayesian networks basics: Tech. Rep. Aalborg University, Denmark.

Leonardo, de C. N.; Jonathan, T. 2002. Artificial Immune Systems: A New Computational Intelligence Approach. Great Britain, 357 p.

Ong, Yl. Z. X.; Tay, J. C.; Kwoh, C. K. 2005. Applying the clonal selection principle to find flexible jobshop schedules, in Proceedings of 4th International Confe-rence "Artificial Immune Systems, ICARIS 2005”. Banff, Alberta, Canada, August 14-17, 2005. 442-455.

Operation of the Aircraft: Annex VI to the Chicago convention on international civil aviation. 2001. 2nd ed.
Захарченко, Ю. А.; Качур, С. Ю.; Корнієнко, О. В. та $i н .2009$. Методика вирішення завдань управління проектами модернізації авіаційної техніки, Вестник Херсонского начіонального технического университета 1(34): 43-47.

Клишин, Ю. 1999. Ставка на модернизацию и многофункциональность, Вестник воздушного флота (1): $18-21$

Руководство по управлению безопасностью полетов. 2009. ИКАО. Изд.второе.

Самков, О. В. 2008. Методичні складові щодо вирішення задач модернізації парку авіаційної техніки в сучасних умовах, Вісник $H A V(1)$ : 2225.

Самков, О. В.; Захарченко, Ю. А. 2009. Застосування алгоритму клонального відбору для побудови планів модернізації авіаційної техніки, Автоматика. Автоматизачія. Електротехнічні комплекси та системи 1(23): 110-114.

Самков, О. В.; Климчук, В. П. 2004. Особливості розробки та реалізації авіаційних цільових комплексних програм в Україні, Вісник НАУ 4(22): 5560.

Самков, О. В.; Литвиненко, В. І.; Ломавацький, І. $€$. та ін. 2008. Оптимізація розподілу фінансів між проектами на основі клонального імунного алгоритму, in Інтелектуальні системи прийняття рімень та проблеми обчислювального інтелекту: Матеріали науково - практичноі конференції. Євпа-торія: ХНТУ. 2008. (3): 182189.

Самков, О. В., Литвиненко, В. І. 2006. Методологічний підхід щодо вирішення завдань розподілу ресурсів в умовах невизначеності, 36 наук. пращь ДНДІ авіачії 21(9): 220-225.

\section{ORO NAVIGACIJOS SISTEMOS ATNAUJINIMO METODOLOGINIAI ASPEKTAI}

A. Samkov, G. Suslova, V. Litvinenko, Y. Zakharchenko

S a n tra k a

Šiame straipsnyje nagrinėjami metodologiniai orlaivių modernizavimo aspektai, iskaitant matematinių metodų, algoritmų ir kriterijų kompleksą, kuris leidžia priimti tam tikrą mokslinị sprendimą.

Reikšminiai žodžiai: aviacijos sistemos, imuninis algoritmas, klonų imuninis algoritmas, Bajeso tinklai, projektų valdymas , efektyvumas, kokybẻ ir skrydžių saugos kriterijai, sprendimų prièmimo ir optimizavimo metodai. 